Дунська А. P.

канд. економ. наук, доцент

Пашенко М. С.

Національний технічний університет Украӥни «КПI»

\title{
АНАЛІЗ СУЧАСНОГО СТАНУ РОЗВИТКУ ТРАНСНАЦІОНАЛЬНИХ КОРПОРАЦІЙ ТА ХАРАКТЕР ЇХ ФУНКЦІОНУВАННЯ В УКРАЇНІ
}

\author{
АНАЛИЗ СОВРЕМЕННОГО СОСТОЯНИЯ РАЗВИТИЯ ТРАНСНАЦИОНАЛЬНЫХ \\ КОРПОРАЦИЙ И ХАРАКТЕР ИХ ФУНКЦИОНИРОВАНИЯ В УКРАИНЕ
}

\section{MODERN DEVELOPMENT STATUS OF TRANSNATIONAL CORPORATIONS AND CHARACTER OF THEIR FUNCTIONING IN UKRAINE}

Дана стаття присвячена особливостям розвитку транснаціональних корпорацій (ТНК) на сучасному етапі та характеру їх функиіонування в Украӥні. На основі аналізу наукових досліджень визначено причини активного розвитку ТНК, а також особливості управління корпорачіями. Розглянуто рейтинги найбільших транснаціональних корпорацій у світі за 2012 та 2014 роки. Наведено коротку характеристику лідируючих світових ТНК. Визначено провідні ТНК за кількістю прачюючих. Представлено поділ трансначіональних корпорачій за виробничою спеціалізачією та країною базування. Наведено порівняння річних доходів ТНК із ВВП деяких країн. Сформовано рейтинг транснаціональних корпорацій за індексом транснаціоналізації. Виокремлено позитивні та негативні фактори впливу на економіку краӥни базування та приймаючої краӥни. Зазначено найбільш привабливі галузі промисловості України для ТНК та інвесторів. Представлено фінансові результати діяльності ТНК за I півріччя 2014 рік в Україні.

Ключові слова: транснаціональна корпорація, структура управління, виробнича спеціалізація, індекс транснаціоналізації.

Данная статья посвящена особенностям развития транснациональных корпораций (ТНК) в настоящее время и характера их функционирования в Украине. На основе анализа научных исследований определень причины активного развития ТНК, а также особенности управления корпорациями. Рассмотрены рейтинги крупнейших транснациональных корпораций в мире за 2012 и 2014 годы. Приведена краткая характеристика лидирующих мировых ТНК. Определены ведущие ТНК по количеству работающих. Представлены разделение транснациональных корпораций по производственной специализации и страной базирования. Приведено сравнение годовых доходов ТНК с ВВП некоторых стран. Сформирован рейтинг транснациональных корпораций по индексу транснационализации. Bыделены положительные $и$ отрицательные факторы влияния на экономику страны базирования и принимающей страны. Отмечено наиболее привлекательные отрасли промышленности Украины для ТНК и инвесторов. Представлены финансовые результаты деятельности ТНК за I полугодие 2014 в Украине.

Ключевые слова: транснациональная корпорация, структура управления, страна базирования, индекс транснационализации. 
This article is devoted to the peculiarities of transnational corporations (TNCs) at present and the nature of their functioning in Ukraine. Based on the analysis of research activities defined causes of TNCs, and especially management corporations. Ratings considered the largest multinationals in the world in 2012 and 2014. Shows a brief description of the world's leading multinationals. Leading multinationals determined by the number of employees. Presented division of multinationals by industrial specialization and home country. The comparison of annual revenues TNC of GDP in some countries. Formed rating transnational corporations transnationalization index. Thesis there is determined the positive and negative impacts on the economy and basing the host country. Indicated most attractive industries for TNK Ukraine and investors. Presented financial results for the first half of TNK in 2014 in Ukraine.

Keywords: transnational corporation, management structure, country-based, index of transnationalization.

Вступ. На сучасному етапі світова економіка характеризується такими процесами, як інтернаціоналізація, глобалізація та транснаціоналізація, які впливають на господарську діяльність усіх країн світу та тісно взаємопов’ язані між собою.

В умовах посиленої інтернаціоналізації світового господарства транснаціональні компанії (ТНК) являють собою могутню частину корпоративного бізнесу, відіграють провідну роль в посиленні та укріпленні світових господарських зв'язків. Своєю виробничо-комерційною діяльністю ТНК фактично пов'язують національні і регіональні ринки, що в свою чергу забезпечує цілісність світового господарства. Жоден процес на світовій арені не відбувається без участі ТНК, які виступають рушійною силою розвитку світової економіки.

На сьогоднішній день у світі налічується близько 82000 ТНК, з яких 80\% розміщено в промислово розвинених країнах і які мають близько 810000 філій в різних країнах на всіх континентах. Втім наслідки діяльності ТНК на ринках приймаючих країн не завжди мають позитивні аспекти для національних економік. Зогляду на це, важливими є питання не тільки ролі транснаціональних корпорацій у світовому господарства, а й особливостей i наслідків їх функціонування на ринках приймаючих країн, зокрема і на ринку України. Тому дане дослідження надасть можливість актуалізувати питання транснаціоналізації українських компанії та розвитку національних бізнесструктур.

Вагомий внесок у дослідження особливостей розвитку транснаціональних корпорацій здійснили такі науковці як Андрушко В. В., Безрукова Н. В., Болгарова Н. К., Косенко В. І., Левківський В. М., Лимонова Е. М., Молчанова О., Пономаренко I. В., Попова А. В., Рокоча В., Хусаінов Булат та інші. Зростаюча кількість публікацій, присвячених даній проблематиці, втім залишає низку недостатньо досліджених питань, а саме постає необхідність подальшого вивчення особливостей розвитку ТНК на 
етапі інтенсивної глобалізації світової економіки та розвитку діяльності ТНК в Україні.

Постановка завдання. Метою дослідження $є$ аналіз сучасного стану розвитку ТНК, визначення ролі транснаціональних корпорацій у міжнародних економічних відносинах та особливостей, що характеризують процес розвитку ТНК та функціонування їх іноземних філій в Україні.

Методологія. В основу проведеного дослідження покладено методологію економічного аналізу, методи статистичного аналізу: порівняння; логічного узагальнення результатів дослідження; графічний метод.

Результати дослідження. Можна стверджувати, що на сьогоднішній день немає жодного значного процесу в світовій економіці, що відбувався б без участі ТНК. Вони приймають участь у світовому політичному процесі, виступають основною силою, яка формує сучасний і майбутній вигляд світу.

Основними причинами активного розвитку ТНК $є$ [1]:

1. Недосконалість ринкового механізму в реалізації власності на технології, виробничий досвід. У рамках ТНК такі активи стають мобільними, здатними до перенесення в інші країни, і зовнішні ефекти використання цих активів не виходять за межі ТНК.

2. Додаткові можливості підвищення ефективності та конкурентоспроможності через доступ до дешевої або більш кваліфікованої робочої сили, сировинних ресурсів, науково-дослідного потенціалу, виробничих можливостей і фінансових ресурсів приймаючої країни.

3. Близькість до споживачів продукції іноземної філії фірми і можливість отримання інформації про перспективи ринків і конкурентний потенціал фірм приймаючої країни.

4. Можливість використання у власних інтересах особливостей державної, зокрема податкової, політики в різних країнах, різниці в курсах валют та ін.

5. Здатність продовжувати життєвий цикл своїх технологій і продукції.

6. За допомогою прямих іноземних інвестицій фірма дістає можливість уникати бар'єрів при входженні на ринок певної країни через експорт товарів та/або послуг.

Кількість ТНК0 значно збільшилася з 1970 року: на той період часу було зареєстровано лише 7000 подібних фірм, сьогодні їх у світі налічується близько 82000 [2].

На основі численних досліджень вчені-економісти дійшли висновку, що наявність філій у багатьох країнах надійніше гарантує стабільність отримання прибутків, ніж такі важливі чинники, як великий абсолютний розмір компанії та міра диверсифікованості ії виробничої програми всередині країни [1].

Ключовою особливістю ТНК $є$ iї структура управління. Батьківська компанія $\epsilon$ центром контролю та прийняття стратегічних рішень. Від 
материнської компанії до філії рухаються товари, капітал, технології управління. Але такі ж самі потоки чинників виробництва можуть спрямовуватися від однієї філії до іншої або навіть від філії до материнської компанії [3].

Серед структур управління ТНК найбільш розповсюдженими $\epsilon$ функціональна, матрична, дивізіональна та змішана структури управління.

Функціональна структура ТНК застосовується поки фірма залишається монотоварною, моноринковою і невеликою, оскільки дана структура володіє швидкою виробничою реакцією і високою конкурентною реакцією. При дивізіональній структурі кожен підрозділ орієнтується на одну групу товарів, або навіть один товар, підрозділи працюють за принципом самоокупності, а центральний апарат лише контролює і координує їх роботу, а також розробляє загальну стратегію корпорації. Матрична структура, яка представляє собою результат накладання функціональної структури на дивізіональну, застосовується компаніями, які прагнуть поєднати дивізіональний підхід 3 товарним i часто з функціональним. Змішана структура містить у собі елементи всіх вищеописаних організаційних структур. При цьому зарубіжний філіал ТНК може не лише засновуватись, а й купуватись: через злиття частини капіталу зі вже існуючою фірмою і через поглинання зарубіжної фірми [3].

Підходи до управління та організаційно-економічної побудови ТНК часто обумовлюють місцем іiі розташування.

Як свідчать дослідження, понад 80\% материнських компаній і близько $33 \%$ афільованих розміщується на території промислово розвинених держав, у країнах, що розвиваються, - відповідно $19,5 \%$ і майже $50 \%$, у колишніх соціалістичних державах - приблизно 0,5\% і 17\% [4].

3500 найпотужніших міжнародних (транснаціональних) компаній (ТНК) 85 контролюють 70\% всіх закордонних інвестицій. ТНК функціонують не в усіх галузях. Ці 500 найпотужніших ТНК реалізують 95\% фармацевтики, 80\% всієї виробничої електроніки і хімії та 76\% продукції машинобудування (виробнича сфера). Більше половини, а саме 60\% міжнародних компаній зайнято у сфері виробництва, $37 \%$ - у сфері послуг і $3 \%$ - у видобувній промисловості і сільському господарстві [2].

Загальний обсяг продажів закордонних філій ТНК у 2013 році склав 34,5 трлн. дол. США (у 2011 році - 21,5 трлн. дол.), а їх сукупні активи перевищили 96,6 трлн. дол. (у 2011 році - 83,8 трлн. дол.). За оцінками ЮНКТАД (конференція ООН з торгівлі та розвитку), сумарна додана вартість закордонних філій ТНК у 2013 році склала 7,5 трлн. дол. (у 2011 році - 6,3 трлн. дол.), що складає більше 10\% світового валового продукту. У 2013 році на закордонні філії припадало трохи більше третини світового експорту $-7,7$ трлн. дол. США. 3 25,5 трлн. дол. сумарних обсягів прямих іноземних 
інвестицій (ПІІ), накопичених до кінця минулого року, переважна частина знаходиться під контролем ТНК [5].

Інвестиційна діяльність ТНК в країни з економікою, що розвивається, продовжує зростати, досягнувши в 2013 р. рекордного рівня в 460 млрд. дол. Разом 3 тим, в країни 3 перехідною економікою (100 млрд. дол.), що становить 39\% глобальних прямих іноземних інвестицій. Інвестиції в розвинені країни практично на одному рівні 3 інвестиційною діяльністю 2012 p. 858 млрд. дол. [6].

За даними рейтингу транснаціональних корпорацій (ТНК) Forbes Китай в 2014 році твердо займає три лідируючі позиції (ICBC, China Construction Bank, Agricultural Bank of China), в порівнянні з 2009 роком в якому США закріпила це місце за собою [4]. До першої десятки даного рейтингу Forbes входять ТНК лише США та Китаю, що свідчить про потужний економічний потенціал обох країн.

Журналом Fortune Global 500 проводяться щорічні дослідження щодо найбільших компаній світу. Основним критерієм складання списку є виручка учасників. Рейтинг Fortune Global 5002012 р. очолила Royal Dutch Shell. Обсяг виручки нафтогазового гіганта склав 484,489 млрд. дол. США. Слідом ідуть Exxon Mobil, Wal-Mart Stores, ВР та Sinopec.

За даними Fortune 500 у 2014 р. (табл. 1), після економічного спаду та фінансової кризи, 500 найбільших компаній світу змогли показати достатньо високий дохід і навіть побити рекорди Fortune Global 500 у 2013 р.. Ïх загальний дохід склав 31,1 трлн. доларів, що на 2,5\% більше порівняно із 2013 p.

Таблиця 1

10 найбільших ТНК світу за версією журналу Fortune, 2014 р., млн.

\begin{tabular}{|c|l|c|c|l|}
\hline № & Назва компанії & Річний дохід & Активи & \multicolumn{1}{|c|}{ Галузь } \\
\hline 1 & Wal-Mart Stores & 476294 & 204751 & Роздрібна торгівля \\
\hline 2 & Royal Dutch Shell & 459599 & 357512 & Видобуток і переробка нафти та газу \\
\hline 3 & Sinopec National & 457201 & 352982 & Нафтохімічна промисловість \\
\hline 4 & $\begin{array}{l}\text { China } \\
\text { Petroleum }\end{array}$ & & 6200651 & Видобуток і переробка нафти та газу \\
\hline 5 & Exхоn Mobil & 407666 & 346808 & Видобуток і переробка нафти та газу \\
\hline 6 & BP & 396217 & 305690 & Видобуток і переробка нафти та газу \\
\hline 7 & State Grid & 333386 & 424531 & Електроенергетика \\
\hline 8 & Volkswagen & 261539 & 446866 & Виробництво автомобілів \\
\hline 9 & Toyota Motor & 256454 & 402422 & Виробництво автомобілів \\
\hline 10 & Glencore & 232694 & 154932 & Оптова торгівля \\
\hline
\end{tabular}

Як бачимо із наведених даних, значних змін у рейтингу протягом 20122014 pp. не відбулося. Одні і ті ж ТНК входять до рейтингу, змінюючи лише позиції та обсяги річних надходжень. 
У Fortune 500 у 2014 р. знаходиться 95 китайських представників (в 2013 р. - 89 компаній). Китайці все міцніше закріплюються в списку лідерів. При цьому американських компаній стало на чотири менше, хоча США і зараз залишається лідером рейтингу. У списку знаходиться 128 корпорацій, у тому числі і №1 Fortune - Wal-Mart Stores, яка $є$ найбагатшою компанією світу і спеціалізується на роздрібній торгівлі.

Royal Dutch Shell, яка зайняла друге місце в Fortune 500, є нідерландськобританською компанією. В 2013 р. у Forbes +2000 визнав iї сьомою за величиною нафтогазовою компанією в світі. У 80 країнах світу у Shell ведеться геологічна розвідка, видобуток газу та нафти. У володінні Shell $€$ більше 13 нафтопереробних заводів. Одним 3 них є нафтопереробний завод Pernis, який вважають найбільшим у Свропі.

Компанія Sinopec посіла третє місце в списку Fortune в 2014 році, а в 2008 році - компанія була ще на шістнадцятому місці. Частка компанії на національному ринку: 73,4\% по природному газу, 60\% по нафті, $41 \%$ по нафтопродуктах.

Протягом декількох десятків років лідером серед країн базування 3 найбільшими ТНК є США (рисунок). Відповідно до рейтингу Global 500 у 2014 р. в США зареєстровано 128 материнських компаній, що входять до 500 найбільших ТНК у світі, 95 - у Китаї, 57 - у Японії, 31 - у Франції, по 28 - у Німеччині і Великобританії, 17 - у Південній Кореї, по 13 - у Нідерландах та Канаді [9].

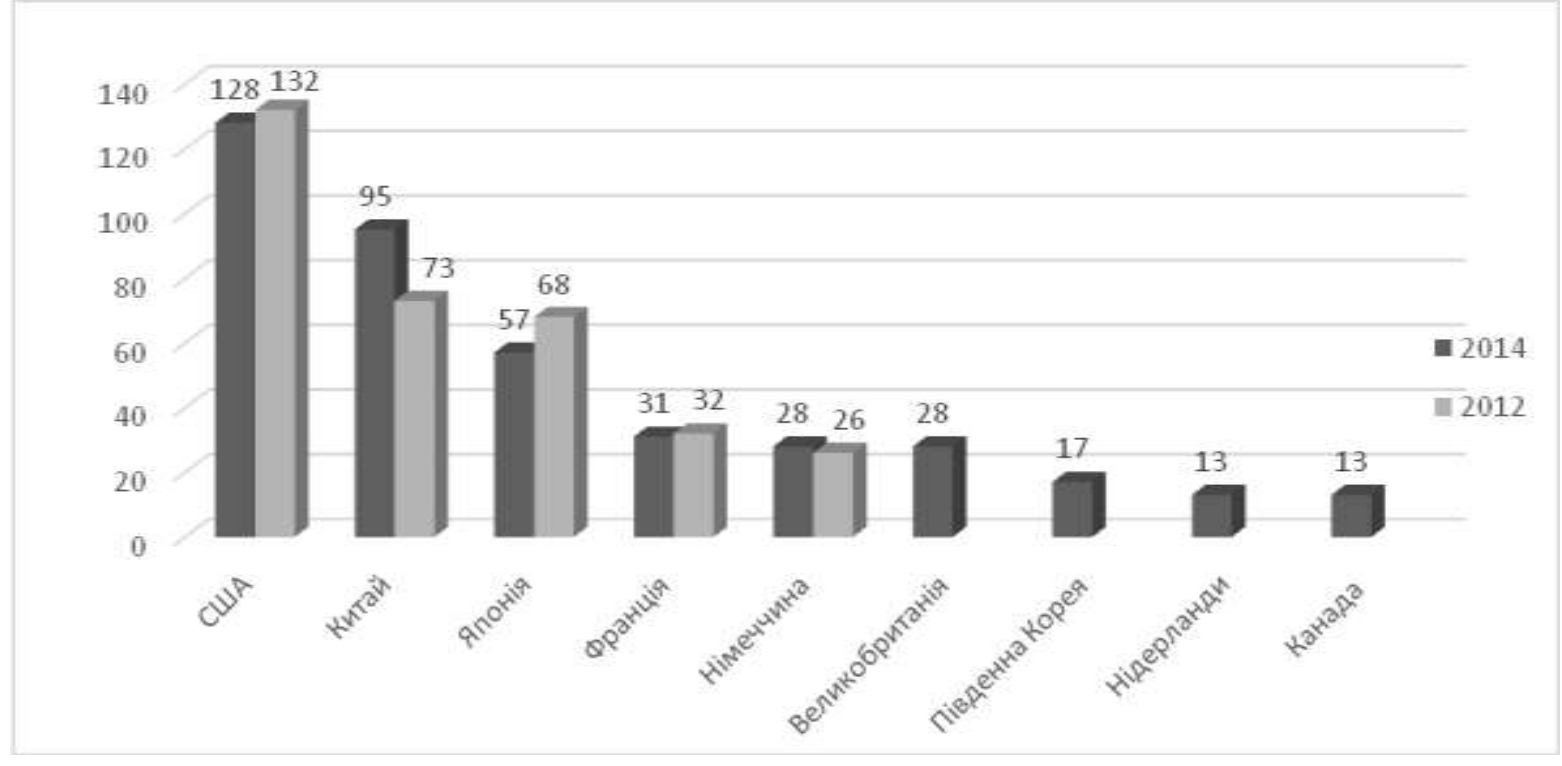

Рисунок. Країни з найбільшими ТНК, 2014 р. [9, 3]

Загальна кількість працюючих в 500 найбільших ТНК світу становить 65 млн. осіб [7]. Рейтинг компаній за кількістю працюючих значно 
відрізняється від рейтингу за обсягами активів та доходів. Лише Wal-Mart Stores вдалось зберегти лідерство (табл. 2).

Таблиця 2

Рейтинг ТНК за кількістю працюючих, 2014 р., млн. ос. [7]

\begin{tabular}{|c|l|c|l|}
\hline $\begin{array}{c}\text { Місце в } \\
\text { рейтингу }\end{array}$ & \multicolumn{1}{|c|}{ Назва компанії } & $\begin{array}{c}\text { Кількість } \\
\text { працівників }\end{array}$ & \multicolumn{1}{|c|}{ Галузь } \\
\hline 1 & Wal-Mart Stores & 2200 & Роздрібна торгівля \\
\hline 4 & China National Petroleum & 1636,532 & $\begin{array}{l}\text { Видобуток і переробка } \\
\text { нафти та газу }\end{array}$ \\
\hline 31 & Hon Hai Precision Industry & 1060 & Електроніка \\
\hline 7 & State Grid & 921,964 & Електроенергетика \\
\hline 143 & China Post Group & 903,357 & Пошта, перевезення \\
\hline 2 & Sinopec & 897,488 & $\begin{array}{l}\text { Нафтохімічна } \\
\text { промисловість }\end{array}$ \\
\hline 8 & Volkswagen & 592,586 & Виробництво автомобілів \\
\hline 137 & U.S. Postal Service & 553,089 & Пошта, перевезення \\
\hline 159 & $\begin{array}{l}\text { Aviation Industry Corp. of } \\
\text { China }\end{array}$ & 535,942 & Аерокосмічна та оборонна \\
\hline 418 & Compass Group & 514,718 & Послуги харчування \\
\hline
\end{tabular}

Обсяг персоналу перших 10 ТНК світу за кількістю працюючих становить 15,1\%, на інші 409 ТНК припадає 84,9\%. Кількість працюючих Wal-Mart Stores становить 3,38\% від загальної кількості зайнятих.

ТНК функціонують не в усіх галузях. Найбільша група ТНК зосереджена в банківсько-фінансовому секторі (табл. 3). До неї входять в основному корпорації США та Китаю.

Таблиця 3

Поділ найбільших ТНК за виробничою спеціалізацісю у 2014 р. [9]

\begin{tabular}{|l|c|l|}
\hline \multicolumn{1}{|c|}{ Сфера діяльності } & $\begin{array}{c}\text { Кількість } \\
\text { ТнК }\end{array}$ & \multicolumn{1}{|c|}{ Країни-засновники } \\
\hline Видобуток нафти і газу & 43 & США, Китай, Росія \\
\hline Банківська-фінансова & 71 & США, Китай, Австралія \\
\hline Виробництво харчової продукції & 9 & Швейцарія, Великобританія, США \\
\hline Високотехнологічне виробництво & 16 & США, Японія, Тайвань \\
\hline Виробництво автомобілів, запчастин & 17 & Японія, Німеччина, США \\
\hline Фармацевтика та біотехнології & 22 & Швейцарія, Франція \\
\hline Сфера роздрібної торгівлі & 17 & США, Іспанія, Мексика \\
\hline
\end{tabular}

Друга найбільш численна група ТНК присутня у сфері видобутку та переробки нафти і газу, третя група ТНК - у сфері фармацевтичного виробництва та біотехнології.

Цікавим $є$ порівняння доходів транснаціональних корпорацій, які входять до сотні великих ТНК світу (2013 р.) і ВВП деяких країн (табл. 4). 
Таблиця 4

Порівняння доходів найбільших транснаціональних корпорацій світу з ВВП деяких країн (2013 р.) [9]

\begin{tabular}{|c|c|c|c|}
\hline $\begin{array}{c}\text { Країна/ВВП (млрд. } \\
\text { дол.) }\end{array}$ & ТНК/доходи (млрд.дол.) & $\begin{array}{c}\text { Країна/ВВП } \\
\text { (млрд. дол.) }\end{array}$ & $\begin{array}{l}\text { TНК/доходи } \\
\text { (млрд.дол.) }\end{array}$ \\
\hline \multirow[b]{2}{*}{ Китай - 489,2 } & Wal-Mart Stores $(469,2)$ & \multirow[b]{2}{*}{ Марокко - 104,8 } & $\operatorname{IBM}(104,5)$ \\
\hline & Royal Dutch Shell $(467,2)$ & & $\begin{array}{l}\text { Agricultural Bank of } \\
\text { China }(103,0)\end{array}$ \\
\hline Австрія - 415,3 & Exxon Mobil $(420,7)$ & \multirow[b]{2}{*}{ Словаччина - 96, 9} & Citigroup $(90,7)$ \\
\hline Казахстан - 224,8 & Chevron $(222,0)$ & & $\begin{array}{c}\text { Procter \& Gamble } \\
\quad(83,3)\end{array}$ \\
\hline Україна - 175,5 & Apple $(164,7)$ & Білорусія - 69,2 & Microsoft $(72,9)$ \\
\hline \multirow{3}{*}{ Угорщина - 130,5 } & General Electric $(147,4)$ & \multirow{3}{*}{ Хорватія - 58,7 } & \multirow{3}{*}{$\begin{array}{l}\text { Mitsubishi UFJ } \\
\text { Financial (59) }\end{array}$} \\
\hline & Ford Motor $(134,3)$ & & \\
\hline & AT\&T $(127,4)$ & & \\
\hline
\end{tabular}

Загальний обсяг продажів 200 провідних ТНК перевищує сукупний ВВП 187 країн світу, що складає більше $30 \%$ світового ВВП при кількості зайнятих менше однієї третини світового населення.

Для характеристики проникнення кожної ТНК в економіку інших країн введено індекс транснаціоналізації компаній (1990р., ЮНКТАД). Цей сукупний показник грунтується на зіставленні розмірів господарської діяльності компанії на батьківщині й за кордоном і складається 3 трьох компонентів: активи, обсяг продажів та штат компанії. В табл. 5 наведено індекс транснаціоналізації деяких ТНК світу.

Таблиця 5

Індекс транснаціоналізації ТНК, 2010 р. [10]

\begin{tabular}{|c|l|c|l|}
\hline Місце & \multicolumn{1}{|c|}{ Корпорація (країна) } & \multicolumn{1}{|c|}{$\begin{array}{c}\text { Індекс } \\
\text { транснаціоналізації\% }\end{array}$} & Галузь промисловості \\
\hline 1 & $\begin{array}{l}\text { Vodafone Group Plc. } \\
\text { (Великобританія) }\end{array}$ & 85 & Телекомунікації \\
\hline 2 & $\begin{array}{l}\text { British Petroleum Plc. } \\
\text { (Великобританія) }\end{array}$ & 80 & Нафтова промисловість \\
\hline 3 & Total S. A. (Франція) & 74 & Нафтова промисловість \\
\hline 4 & $\begin{array}{l}\text { Royal Dutch/Shell Group } \\
\text { (Великобританія/Нідерланди) }\end{array}$ & 70 & Нафтова промисловість \\
\hline 5 & Еххоп Моbil Сorp. (США) & 68 & Нафтова промисловість \\
\hline
\end{tabular}

На основі табл. 5 можна зробити висновок, що Vodafone Group Plc. мала найвищий ступінь залученості надання послуг за кордон. В 2010 р. найвищі показники мали ТНК, що спеціалізуються на нафтовій промисловості (видобування, переробка). 
Максимальний індекс транснаціоналізації за галузями мають ТНК у засобах масової інформації (82\%), в металургійній і гірничій промисловості (65\%), у нафтовій і газовій промисловості (63\%).

За даними «Доповіді про світові інвестиції» ЮНКТАД, в Україні було зареєстровано 367 іноземних філій ТНК станом на кінець 2012 р., тоді як у багатьох країнах СНД цей показник $є$ значно вищим. Зокрема, кількість іноземних ТНК у Молдові сягає 2670, у Росії - 1176, у Казахстані - 1772 [11]. В Україні присутній менш ніж 1\% усіх світових ТНК.

Втім слід розуміти, що функціонування ТНК неоднозначно впливає на економіку країн. На основі аналізу досліджень науковців виокремлено позитивні та негативні фактори впливу на економіку країни базування та приймаючої країни (табл. 6).

Таблиця 6

Вплив ТНК на економіку приймаючої країни та країни базування [9]

\begin{tabular}{|c|c|c|}
\hline 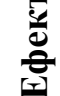 & Приймаюча країна & Країна базування \\
\hline 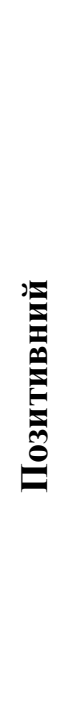 & 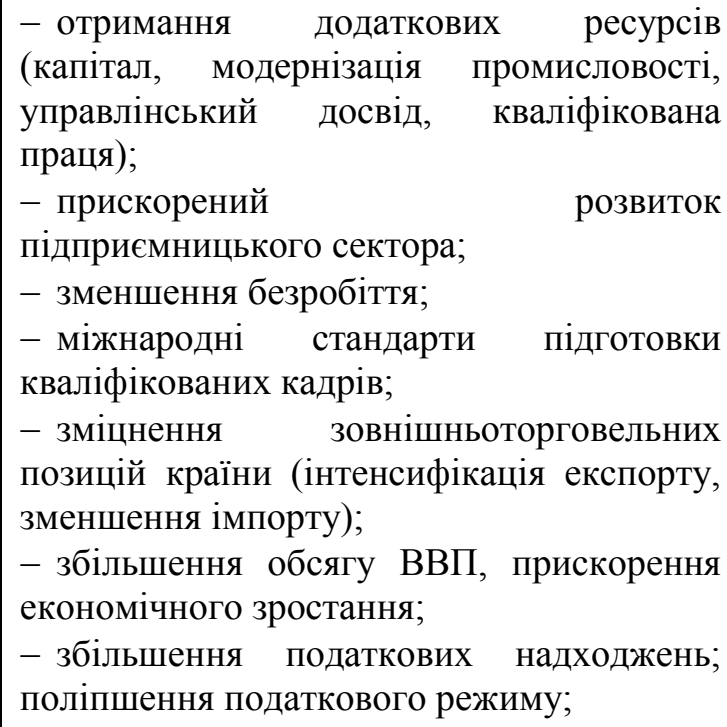 & $\begin{array}{l}\text { - доступ та певний контроль над природними } \\
\text { ресурсами приймаючих країн; } \\
\text { - врахування розбіжностей в екологічних } \\
\text { нормах і стандартах між країнами; } \\
\text { - стимулювання попиту на продукцію країни } \\
\text { базування ТНК; } \\
\text { - зменшення витрат на освіту фахівців за } \\
\text { рахунок їх залучення з приймаючих країн; } \\
\text { - доступ до інформаційних ресурсів інших } \\
\text { країн; } \\
\text { - підвищення ефективності національного } \\
\text { експорту; } \\
\text { - зміцнення платіжного балансу країни; } \\
\text { - політичний вплив у світі; }\end{array}$ \\
\hline & $\begin{array}{l}\text {-маніпуляції в ціноутворенні; } \\
\text {-представники приймаючої країни не } \\
\text { допускаютьяя до участі в проведенні } \\
\text { НДДКР; } \\
\text {-посилена експлуатація і встановлення } \\
\text { зовнішнього контролю з боку ТНК; } \\
\text {-ТНК можуть використовувати застарілі } \\
\text { технології виробництва; } \\
\text {-недотримання ТНК екологічних } \\
\text { стандартів і проблема Greenwash; }\end{array}$ & $\begin{array}{l}\text { - можливий політичний тиск ТНК на уряд; } \\
\text { - «експорт робочих місць», що збільшує } \\
\text { безробіття; } \\
\text { б зменшення податкових надходжень до } \\
\text { бюджету за рахунок використання ТНК } \\
\text { трансфертних цін або перенесення діяльності до } \\
\text { інших країн; } \\
\text { - державне регулювання іноземних інвестицій } \\
\text { (заборона на інвестування в окремих галузях, } \\
\text { особливі умови інвестування); } \\
\text { - проведення НДДКР в приймаючій країні. }\end{array}$ \\
\hline
\end{tabular}


Україна викликає особливий інтерес ТНК у тих галузях, в яких яскраво виражені конкурентні переваги щодо національних компаній. У 2013 р. найбільш привабливими для ТНК та інвесторів із країн Свросоюзу та США були такі галузі української економіки: харчова промисловість та переробка сільськогосподарських продуктів $(15,7 \%$ від загального обсягу прямих іноземних інвестицій; торгівля $(15,6 \%)$; фінансова сфера $(8,5 \%)$; машинобудування $(8,0 \%)$; транспорт $(7,6 \%)$; операції з нерухомістю $(4,6 \%)$; фармацевтика та нафтохімічна промисловість $(4,1 \%)$ [12].

Сьогодні в Україні найбільша кількість ТНК представлена у переробній промисловості. За версією Forbes, за підсумками першого півріччя 2014 р. більшість з них була прибутковими (табл. 7) [13].

Таблиця 7

Фінансові результати ТНК в Україні за I півріччя 2014 р. [13]

\begin{tabular}{|r|l|l|c|c|}
\hline \multirow{2}{*}{ № } & \multicolumn{1}{|c|}{ Корпорація } & Галузь & $\begin{array}{c}\text { Виручка за I } \\
\text { півріччя 2014 р., } \\
\text { млн. дол. }\end{array}$ & $\begin{array}{c}\text { Виручка за 2013 } \\
\text { р., млн. дол. }\end{array}$ \\
\hline 1 & JT International & Тютюнова & 3776,7 & 7103,7 \\
\hline 2 & Philip Morris & Тютюнова & 2907,3 & 5675,1 \\
\hline 3 & Imperial Tobacco & Тютюнова & 2233,8 & 4299,4 \\
\hline 4 & Bunge & Агропромислова & 2088,4 & 5623,4 \\
\hline 5 & ViOil & Харчова & 2259,9 & 3359,8 \\
\hline 6 & Nestle & Харчова & 2443,4 & 5305,5 \\
\hline 7 & Shell & Нафтогазова & 1720,6 & 4155,8 \\
\hline 8 & Tоуота & Машинобудування & 1861,9 & 577,6 \\
\hline 9 & Procter\&Gamble & Хімічна & 2691 & 6068,5 \\
\hline 10 & PepsiCo & Харчова & 3273,5 & \\
\hline
\end{tabular}

Найбільшу виручку від реалізації продукції за I півріччя 2014 р. отримали ТНК, що працюють в тютюновій та харчовій галузях промисловості, а саме: JT International, PepsiCo та Philip Morris.

Сьогодні в Україні працює значна кількість ТНК в різних галузях, проте роль ТНК в економіці України не варто перебільшувати. Їхня діяльність спрямована переважно на національний ринок. Відносно мало компаній прийшли для того, щоб виробляти товари на експорт. Проте присутність ТНК в Україні забезпечує імпорт ефективних технологій виробництва, підвищення ефективності менеджменту, зменшення безробіття та збільшення грошових надходжень в країну.

Висновки. Отже, проведене дослідження доводить, що діяльність транснаціональних корпорацій є важливою для економіки будь-якої країни i Україна $\epsilon$ не винятком. Рівень інтегрованості країни, ії участь в міжнародному поділі праці та глобальна конкурентоспроможність дедалі більше залежить від успішної діяльності ТНК. 
Наукова новизна статті полягає у аналізі діяльності транснаціональних корпорацій на сучасному етапі та визначення характеру їх діяльність в Україні. Аналіз фінансових результатів діяльності ТНК надає можливість конкретизувати вектор співробітництва та розвитку їх діяльності на території України.

Україна має значний потенціал розвитку співпраці з ТНК і потребує законодавчих, правових та економічних змін, щоб створити сприятливий інвестиційний клімат для розміщення дочірніх підприємств провідних ТНК світу i, як наслідок, збільшення капіталовкладеннь в економіку країни.

\section{Література:}

1. Рокоча В. Трансакційні корпорації [Електронний ресурс]: Бібліотека онлайн. Режим доступу: http://readbookz.com/book/50/2010.html

2. Попова А. В. Транснациональные корпорации как субъект международных экономических отношений [Електронний ресурс]: VIII Международная студенческая электронная научная конференция. - Режим доступу: http://www.scienceforum.ru/2015/pdf/9917.pdf.

3. Комшук О. І. Трансформація системи управління ТНК в умовах глобальної конкуренції та посилення ролі науково-технічного прогресу [Електронний ресурс]: Бібліотека ДВНЗ КНЕУ ім. Вадима Гетьмана - Режим доступу: http://ir.kneu.edu.ua:8080/bitstream/2010/4465/1/Komshuk.pdf

4. Побоченко Л. М. Аналіз інвестиційної діяльності транснаціональних корпорацій [Електронний ресурс]: Наукові журнали Національного Авіаційного університету. - Режим доступу: http://jrnl.nau.edu.ua/index.php/SR/article/view/7022

5. Хусаинов Булат Транснационализация - глобальный вызов [Електронний ресурс]: «Деловая неделя». - Режим доступу: http://dn.kz/?option=com_content\&view=article \&id=2273\%3A-s- $\&$ catid=5\%3A2011-10-23-11$45-05 \&$ Itemid $=16$

6. Global investment trends monitor [Електронний ресурс]: UNCTAD.- Режим доступу: http://unctad.org/en/PublicationsLibrary/webdiaeia2014d5_en.pdf

7. Fortune Global 500 [Електронний pecypc]: Fortune. - Режим доступу: http://fortune.com/global500/

8. Fortune Global 5002014 - рейтинг крупнейших компаний мира. - Режим доступу: http://www.stevsky.ru/reytingi-forbs/fortune-global-500-2014-reyting-krupneyshich-kompaniymira

9. Лимонова Е.М., Воробйова К.О. Дослідження впливу ТНК на країни базування та приймаючі країни [Електронний ресурс]: Дніпропетровський університет ім. Альфреда Нобеля. - Режим доступу: http://duep.edu/uploads/vidavnitstvo14-15/10107.pdf

10. Гудим К. Транснаціоналізація як чинник глобалізації [Електронний ресурс]: Вісник КНТЕУ. - Режим доступу: http://visnik.knteu.kiev.ua/files/2014/04/4.pdf

11. Андрушко В. В. Особливості діяльності ТНК в Україні [Електронний ресурс]: Міжнародна науково-практична інтернет-конференція. - Режим доступу: http://professura.at.ua/forum/19-157-1

12. Латинін Д. О. Стан та перспективи розвитку ТНК в світі та Україні [Електронний pecypc]: Publishing house Education and Science s.r.o. - Режим доступу: http://www.rusnauka.com/38_NIEK_2014/Economics/2_181324.doc.htm 
13. Іванова Н. В. Перспективи розвитку транснаціональних корпорацій в Україні в умовах економічної кризи [Електронний ресурс]: Publishing house Education and Science s.r.o. - Режим доступу: http://www.rusnauka.com/11_NND_2015/Economics/3_190997.doc.htm 